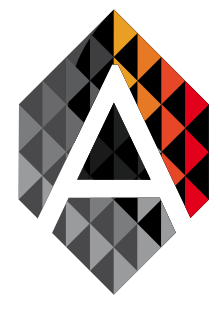

ADCAIJ: Advances in Distributed Computing and Artificial Intelligence Journal Regular Issue, Vol. 8 N. 3 (2019), 51-65

eISSN: 2255-2863

DOI: http://dx.doi.org/10.14201/ADCAIJ2019835165

\title{
The Importance Of Development of Control Processes and Methods for Urban Bus Services
}

\author{
Eduardo Facchini ${ }^{\mathrm{a}}$ and Eduardo Mario Dias ${ }^{\mathrm{b}}$ \\ ${ }^{a}$ Escola Politécnica Da Universidade de São Paulo \\ ${ }^{\mathrm{b}}$ USP \\ eduardofacchini@usp.br,emdias@pea.usp.br
}

KEYWORD

urban mobility; public transport; externalities; operation; control

\section{ABSTRACT}

This article aims to discuss the importance of the development of methodologies and control processes by the public power for the proper management of the urban bus system. It reflects on the idea of management control from the perspective of an operational, strategic and innovative perspective. It proposes a new look at the solution of negative externalities that arise in the urban environment of cities such as collisions, roadkill, works that will obstruct the roadbed and various events disrupting local traffic and directly impacting the mobility of public transport on tires. The theme is current, as it addresses the most problematic urban problem in the contemporary world, which is mobility. Thus, the article tells the experience of São Paulo and discusses a new control methodology for urban bus service.

\section{Introduction}

In certain large contemporary cities, we encounter certain negative externalities related to urban mobility that need to be addressed to improve the daily lives of their citizens.

These externalities result from accidents involving motor vehicles, traffic jams and even the lack of urban mobility caused by known factors, such as the absence in some of these large public transport centers suitable for the movement of large numbers of its population, such as subways or lines of transport. trains, qualified by high capacity transport.

We still have to include in this relationship the demographic distribution between housing and work in the question of "land use and occupation", which usually develops without due planning over the years, forcing the population to make long commutes and commuting movements in their displacements. daily to meet your needs.

Finally, yet another indispensable factor to bear in mind is the issue of standardized time as the responsible business in the background really for all the jams and times known as "peak" or " rush", as Foucault (2014) would say the heritage of schedule. In this scenario the bus, an element that tries to compensate for the lack of mass transportation in these large cities, is the most affected in the travel time, and its passengers.

Eduardo Facchini and Eduardo Mario Dias The Importance Of Development of Control Processes and Methods for Urban Bus Services
ADCAIJ: Advances in Distributed Computing and Artificial Intelligence Journal Regular Issue, Vol. 8 N. 3 (2019), 51-65 elSSN: 2255-2863 - http://adcaij.usal.es Ediciones Universidad de Salamanca - CC BY NC DC 


\subsection{Brazil and the bus}

Public transportation on tires in Brazil is of fundamental importance in the daily life of the population, since it means, in many situations, the only means of public transportation between residence, work, school and religious and leisure activities. Among public transportation, the bus is the most adopted by the public power in Brazil, in fact for the high cost of investment of rail-rail modes for Brazilian municipalities.

However, one of the crucial problems faced by bus service users in Brazil, and especially in Sao Paulo, among others, is a simple but centrally difficult difficulty in our study. Not knowing the approximate time, let alone the exact departure time, for a personal schedule in your day to day.

Often not only due to the lack of an efficient information system, but in most cases the bus is subject to negative externalities such as traffic, road events etc. One more observation that should be made concerns the frequency of a bus line, which is measured by time scales, different from the São Paulo subway, for example, which has its measurement made at intervals, similar to the drum cadence in a march of soldiers. in battalion, exemplified by Foucault (2014).

On the other hand, when we make service schedules such as the bus schedule or any service public, we are within the general 'control' of bus users. And the user becomes the service inspector himself assisting the managing power in some cases.

The aim of this paper is to provoke a reflection and make a conceptual discussion between the control model used today in the urban bus service and the intended one, using for this purpose the São Paulo model while seeking to complement the literature on the subject. To achieve our purpose, we will briefly describe the current and historical situation of this service in the city of São Paulo.

This city has faced problems of various kinds with regard to public transportation on tires, the municipal urban bus service, and has a great deal of experience on the subject, and is the place where the proposal of a of the studies here focused as a case study called Controlled Operation.

\section{Sao Paulo's Experience - A Case Study}

Currently São Paulo has two types of contracted operators, one, the companies called Dealers, another, the cooperatives of the old unauthorized vehicles nicknamed "turkeys", because they had " turkey" vehicles, today called Permissionaires.

The system fleet is composed of 15 thousand vehicles, being 10 thousand from concessionary companies and 5 (five) thousand from cooperatives and small permissionaires companies. According to Wright (1986), it is a relevant factor and, therefore, also important to say here that the "ideal dimension of transport service operators is an essential issue in the discussion about the organization of public transport", since the fleet São Paulo bus station is considered the largest in Latin America.

In the case of São Paulo, a broad and enthusiastic debate would be necessary to show this importance, since part of the permissionary operators still bet on growth. Fact that has generated an endless "arm wrestling", with the government that granted them the precarious authorization and that is the document that guarantees them to render service to the system. The other part of the permit holders seeks to establish themselves as companies in the sector like any other concessionaire.

\section{SAO PAULO TRANSPORTE SA - SPTRANS}

The company Sao Paulo Transporte SA was incorporated on March 8, 1995, with the purpose of managing the transportation system of the city of São Paulo (SPTRANS, 2015). It is made up of remaining employees of the former CMTC, which stands for Companhia Municipal de Transportes Colectivos, a public company operating the system since 1947, and extinguished by the then mayor engineer Paulo Salim Maluf in 1994.

In 2013 the newly elected administration decided to set up a group to study the processes related to municipal bus system controls due to poor performance and poor start-ups. The idea was to work on a new concept that offered and guaranteed to the urban public bus system safety, quality, reliability and comfort level similar to the São Paulo Metro.

Eduardo Facchini and Eduardo Mario Dias The Importance Of Development of Control Processes and Methods for Urban Bus Services
ADCAIJ: Advances in Distributed Computing and Artificial Intelligence Journal Regular Issue, Vol. 8 N. 3 (2019), 51-65 eISSN: 2255-2863 - http://adcaij.usal.es Ediciones Universidad de Salamanca - CC BY NC DC 


\subsection{Bus Contracting Scheme}

The public bus transportation service by bus in São Paulo is provided by two groups of contracts as already mentioned, and title information following clarifications:

Concession Agreement - signed with companies that operate the services, through a bidding process, each concessionaire being remunerated by passengers carried by it, regardless of the fixed value of the public tariff.

Permission Agreement - signed with cooperatives of small operators and some companies, which operate, precariously, the services, each Permissionaire also being paid by passengers carried by it, regardless of the fixed value of the public fare.

There being no differences in their compensation per passenger, they are only in the labor and social security issue, in addition to the compensation amount characterized by virtue of the investment made in its operation, distinct. For the purpose of this article, we will name as both Concessionaire and Permissionaire operators, seeking a better understanding.

Today in the same region are allowed to operate vehicles of various sizes, although when designed, the system provided that it was divided and designed to be operated on two distinct fronts: Structural System and Local. Larger vehicles in the Structural System, with itineraries that run through the city's structural road, operated by the Concessionaires, and Local System, with smaller vehicles, in neighborhood streets and roads, operated by the Permissionaires.

Despite the projected, in the natural alternation of political management, operators and different types of vehicles ended up mixing in the two systems, being allowed even until second order, that one penetrated the operational territory of the other, allowing the manager, SPTrans, to manage this dispute. Operators are responsible for the various aspects that make up the current system:

- Fleet supply and fixed and shipped location and communication equipment;

- Provision of the necessary infrastructure to provide services such as garage, workshops and administrative facilities;

- Provision of human resources necessary for the operation and maintenance of the fleet involved and;

- Fleet Operational Control Management in service.

Regarding the contractual structure, it is the responsibility of SPTrans to monitor and inspect the services.

\section{Literature Elements}

In this section we will make a brief exploratory analysis of the literature on the main concepts and themes surrounding the development of processes and controls for urban bus transport.

\subsection{Bus control in Sao Paulo}

It is important to inform that the control is currently exercised by the operators themselves, who receive from the managing body (SPTrans) a work order which they must comply with. The pitfalls in postindustrial urban sprawl, especially in so-called Third World metropolises such as Sao Paulo in a globalized economy, accentuate social disparities and open the door to new, ambitious and unethical administrative methodologies.

The fact is that nowadays it is not possible for the Public Power, here in this case the São Paulo City Hall, represented by the Municipal Department of Transport and SPTrans, holders of the power of public lines concession, are waiting only for the goodwill of the bus service business so that the service can be fulfilled with the effectiveness and efficiency due to such a relevant service.

Thus, the course chosen by the study group was to address the issue of control and to verify what we should really keep under control. In seeking the etymological origin of the word CONTROL for the purpose of conceptualization, we find that the term comes from medieval Latin, against rotulum, which in French evolved into counterrole, forming the word we know 'control'. (GUALAZZI, 1992 apud LUNKES, 2010).

Eduardo Facchini and Eduardo Mario Dias The Importance Of Development of Control Processes and Methods for Urban Bus Services
ADCAIJ: Advances in Distributed Computing and Artificial Intelligence Journal Regular Issue, Vol. 8 N. 3 (2019), 51-65 eISSN: 2255-2863 - http://adcaij.usal.es Ediciones Universidad de Salamanca - CC BY NC DC 
Foucault (2014) in his work Watch and Punish 1975 devotes an extensive chapter to control, which he calls: The Control of Activity. The philosopher goes from the seventeenth to the nineteenth century showing how the first forms of control emerged, from the monastic communities responsible for the diffusion, according to the author, of the issue of time, quickly spread to schools, workshops and hospitals. The trajectory of the concept goes beyond the rigid discipline of schedules in both schools and industry, as well as controlling the march of a troop in the early seventeenth century. It also talks about the disciplinary control of the soldier's posture, gait and student's posture to better write and learn, which should be taught by the teachers of the time.

In spite of the excellent study of the philosopher, it is certain that we can affirm by performing a simple exploratory analysis in the existing literature on the subject, that the concept of control from the unique and universal point of view does not exist.

“Thirteen years later Deleuze (1992, p. 219-26) will formulate the theory of a new social order which he will call the controlling society. For the theorist, it was in the second half of the twentieth century - after World War II - that disciplinary societies gave way to societies of control. After the end of World War II, forces arose in society that established a new order. These forces would be identified with changes that took place throughout the capitalist world, linked mainly to technological innovations. The use of these new technologies for social control would be the newest expression of the exercise of power in modern society"(AGUERO, 2008).

According to Lunkes (2010) it is observed that there are different definitions depending on the subject, and even the language used, as the word also suffers a variation of meaning in certain languages.

One must also recognize the practical difference between monitoring and controlling, which is effectively exercising control. And monitoring is observing and recording routines for probable regulation if it is the case of a system. Monitoring: Its purpose is to provide managers with simpler and timely information about program operation and effects, summarized in monitoring indicator panels or systems. (JANNUZZI, 2009, p.124)

Therefore, monitoring is what we can observe, through electronic instruments or not, as any internal elevator monitoring system in a building, for example, where access control is usually done by door entry or turnstiles.

When we focus on perhaps the most difficult of our problems, the obstacles that city buses must overcome. We immediately considered our eventual allies, including the traffic lights. According to Oliveira Neto (2004) the semaphore strategy of isolated control is the simplest existing system. Which seems to us only half true, as we fail to consider physical space:

"When we discuss the road space and the democratic distribution that should take place over it, we find that there has been no new way out of the problem, except for restrictive policies such as plate rotation per day, restriction of circulation. of the load in a certain time slot in the city, urban toll proposal etc. Unlike the question of the car's relationship with the environment, about the physical space has been given little thought". (MORAES; FACCHINI; BOVO, 2014, p. 60)

It is true that we must consider all aspects of promoting public bus prioritization in the urban setting, including traffic light, but the fact that road space is finite must be taken into account. The first urban traffic control systems, according to Wood (1993), aimed to improve the circulation and flow conditions exclusively of private vehicles. Over time, these objectives have expanded to include, among others, maximizing pedestrian and transport safety such as cycling and animal-driven transportation, as well as reducing fuel consumption and polluting emissions, improving environmental conditions, and only recently, the prioritization of public transport.

\subsection{Urban Bus Operating System}

Another important element that we must shed light on in order to understand what is intended to be achieved with the São Paulo controlled operation is the conceptualization of the urban bus operation system. This in its essence is simply a set of elements and / or subsystems, which act simultaneously or synchronously, and always aims to achieve a quality goal and can and should have monitoring and control.

Eduardo Facchini and Eduardo Mario Dias The Importance Of Development of Control Processes and Methods for Urban Bus Services
ADCAIJ: Advances in Distributed Computing and Artificial Intelligence Journal Regular Issue, Vol. 8 N. 3 (2019), 51-65 eISSN: 2255-2863 - http://adcaij.usal.es Ediciones Universidad de Salamanca - CC BY NC DC 
Thus, a transport system can be of any size and or complexity. For example, an airline's operating system has a certain set of complexity and sophistication, unlike a pizza restaurant's delivery system, with completely different dimensions and complexity.

Even though it seems obvious the importance of discussing the purpose and how to exercise control in the urban bus transport system, due to the relevance of the service, it is important to analyze that this mode of transport is subject to the unexpected of the way in which it travels, streets and avenues.

The peculiarities of urban public transport should be analyzed from its service characteristics, which involves dimensions such as: intangibility; simultaneity between production and consumption; difficulty in standardization; heavy dependence on the human factor; irregular demand, not allowing stability and uniformity in production; extra-wall production with large geographical dispersion, in an uncontrollable environment, subject to several variables (topography, urban layout, traffic, etc.); the market is regulated and generally with little differentiation in service delivery; It also considers the context of the transport system in the region, which includes the providers of this service, constantly monitoring the relationship between the main actors of the process: users (demand), entrepreneurs (supply) and public authorities (regulator). (CRUZ, 1998, p. 46)

This environment, when observed in the daily life of cities, demonstrates a high degree of possibility that there are events beyond any control and without the slightest governability by public service managers, causing temporary or long-term traffic impediments in the road where its displacement should happen, thus severely impairing the provision of this service. It is true that the government seeks in its contracts with operators to ensure that the contractor does not perform the service, almost always using the supervisory power and pecuniary sanctions inherent to public managers.

Surveillance is thus employed in the regulatory order of the concession and may cover various points of view, such as:

- The practical, allusive to the fulfillment of the service object of the contract;

- The technician, referring to what meets the requirements established in the specifications, approvals and contractual clauses;

- The financial, necessary for the definition of tariffs and verification of the economic-financial balance of the concessionaire's operators;

- And the legal, which concerns the contractual legal issue.

Among the various obligations of inspection processes are:

- An analysis of the technical and economic prerequisites, defining the concession compliance level;

- Have as a satisfactory average the quality conditions that the service should be offered to users;

- Proof of compliance by the concessionaire with the operating service orders (OSO) issued by the contractor.

Thus we can see that to supervise the urban bus service is necessary to monitor and control the contracted service, because even if the government can make the operator do what should be done according to the need of the service, would still have to overcome the unexpected., or rather, the unforeseen events amid the itineraries of the set of lines that make up the urban bus system. We can verify then that the central difficulties are the lack of organization and methods in the process of inspection, monitoring and control of the service.

When we make a comparative analysis with other transport systems, we see our difficulties in this type of system due to the occurrences and lack of control of this environment. The metro-rail or rail system, for example, shows a different scenario, as externalities are predictable, and can be calculated, or better yet, appropriate control routines and procedures can be provided for each situation. And again, it is important to say that unpredictable events happen on a smaller scale, because the scenario is well delimited. Even so, their monitoring and control systems are redundant and robust because they must predict random events that occur in that environment, which does not occur in urban tire systems.

Eduardo Facchini and Eduardo Mario Dias The Importance Of Development of Control Processes and Methods for Urban Bus Services
ADCAIJ: Advances in Distributed Computing and Artificial Intelligence Journal Regular Issue, Vol. 8 N. 3 (2019), 51-65 eISSN: 2255-2863 - http://adcaij.usal.es Ediciones Universidad de Salamanca - CC BY NC DC 


\subsection{We manage only what we control}

"To control is to make sure that everything happens according to the established rules and the orders given." (FAYOL, 1981, p. 26).

In discussing the public transport system operation is essential talk a little about and control system so broad sensus to know what seek for the sector. As we said, the word control can have varied concepts and various meanings. Chiavenato (2003, p.176) shows three of the most frequent ones:

1. Control as a restrictive and coercive function. Used to curb or limit certain types of unwanted deviation or unacceptable behavior. In this sense, the control has a negative and limiting character, being often interpreted as coercion, delimitation, inhibition and manipulation. It is the so-called social control applied to organizations and society to inhibit individualism and people's freedom.

2. Control as an automatic regulation system. Used to automatically maintain a constant degree of flow or operation of a system. This is the case of the automatic control process of oil refineries, continuous and automatic processing chemical industries. The control mechanism detects possible deviations or irregularities and automatically provides the necessary adjustment to return to normal. When something is under control it means it is within normal.

3. Control as an administrative function. It is control as part of the administrative process, such as planning, organization and direction.

Lunkes $(2010$, p.3) in his research on the concept of control claims that the concepts described by several authors on the subject converge to the conviction that the controls have in common, a comparative analysis between the "ideal and the real". Control, therefore, is the procedure by which confrontations are made, between the scheduled (ideal) and the realized (actual), with the information about the execution of the processes previously planned.

In the case in point, the control we seek for the urban bus service fits these concepts, the three of Chiavenato (2003), and the one of Lunkes (2010), because when programming an urban line we issue a timetable that we want. Therefore, the operator would be the "idealized" and the "realized" part, which was actually fulfilled by the contractor. As our approach is systemic, we should consider scientific considerations, essentially those that bring concepts and research on General Systems Theory.

As already mentioned, a Transport Operation System always aims to achieve a quality goal and can and should have monitoring and a certain level of control, both linked to subsystems inserted in the context of the operation process. To better understand what a control system or circuit is and deepen our reflection, let's stick to two of them.

According to Mosimann and Fisch (1999) they can be classified into closed or open control system (circuit). In the case of closed controls we can say that it is like the electrical system of a home, where the basic service requirements are already pre- calculated and the information is fed back by the system itself. The control is made by clocks of the energy to be used and by circuit breakers, in case of any abnormality in the power grid. In this case, the system employed produces all the information indispensable to the realization of the control system.

With regard to the open control system, for example, already getting into our subject we can cite the transport systems themselves in general. Open control system is one in which the information produced by the system itself is not enough to complete the circuit. It ends up requiring the interference of an external decision-making component through its evaluation and deliberation, using process complementation with external input (information). Normally, in the case of the bus, the line inspector, any operator or even public employee.

\section{Controlled Operation And The Pilot Project}

In the case of an open control system, such as the transportation system, it is essential to establish routines and procedures in order to minimize the risks of unforeseen events. It is essential to look for elements such as

Eduardo Facchini and Eduardo Mario Dias The Importance Of Development of Control Processes and Methods for Urban Bus Services
ADCAIJ: Advances in Distributed Computing and Artificial Intelligence Journal Regular Issue, Vol. 8 N. 3 (2019), 51-65 elSSN: 2255-2863 - http://adcaij.usal.es Ediciones Universidad de Salamanca - CC BY NC DC 
well-structured and dynamic procedures manuals, where the operation team can lay their foundations and set the desired standard for the service.

So let's talk about how the pilot experiment was set up at dawn lines using Controlled Operation as a method. In the case in point it was defined that the command would be made by SPTrans (contractor), a factor that would change the structure and the rule of the game, with the Government re-commanding the operation, not only defining the departure times, but establishing the departure time.

The technology used in the transportation system of the city of São Paulo is composed of equipment embedded in the vehicles, such as the validator for the control of the ticket, known as the Single Ticket (BU) - it is the instrument used in the city of São Paulo to enable the various tariff policies implemented, such as: Monetary Standard Credits, where payment of a tariff allows up to four shipments, within two hours or a time tariff in the daily, weekly and monthly modalities), and other subsystems and systems software and process support. Figure 1 illustrates the set of embedded control equipment.

\section{Equipamentos Embarcados}

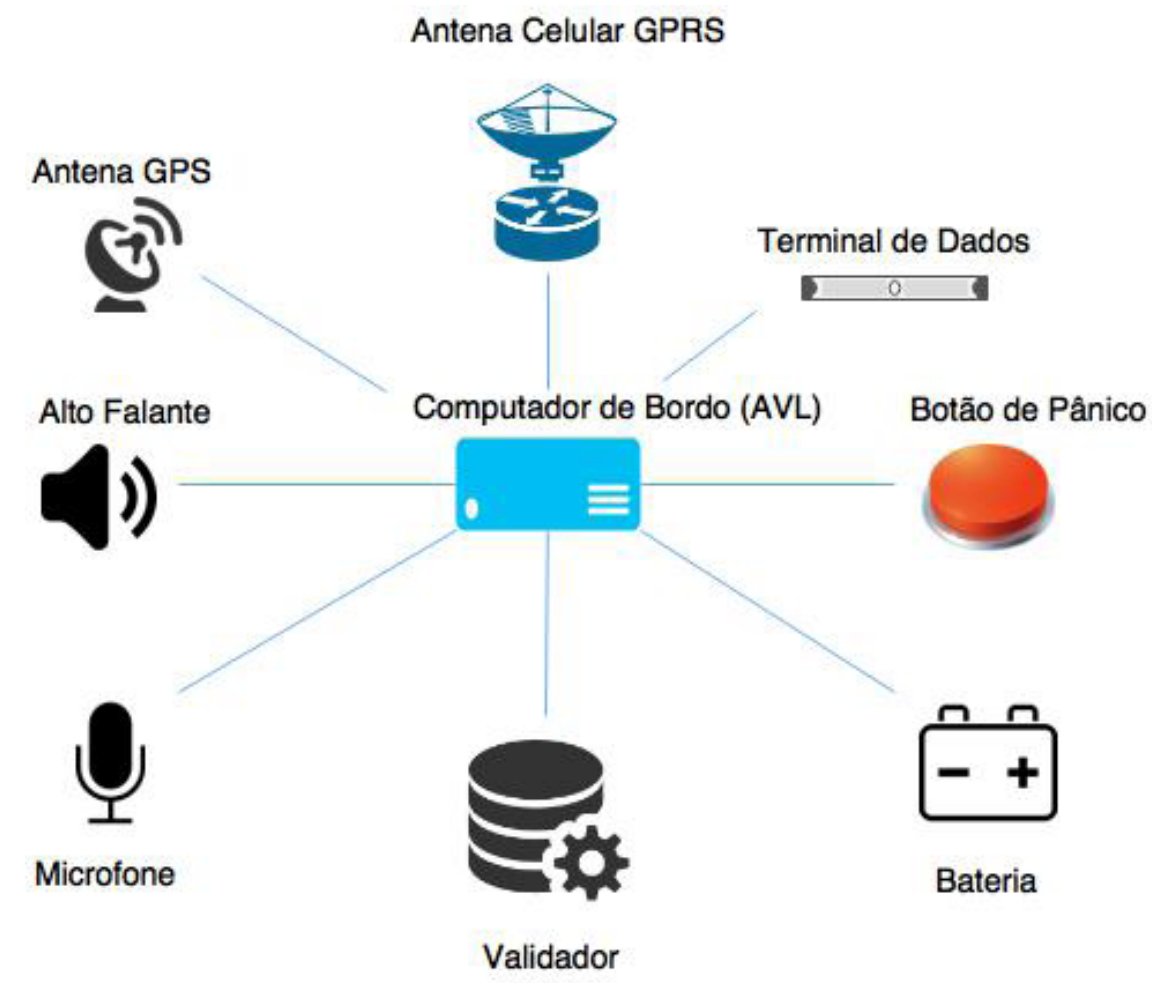

Figure 1: Schematic drawing of the embedded equipment of the São Paulo vehicular fleet.

\section{Source: May 2009 SPTrans Management \& Revenue Board Report}

One of these systems SPTrans began its development in 2002, the Info- Trans system, when the company sought to improve obsolete applications for the time.

Yet the applications did not use geo-processing tools connected to a relational database in an intranet (WEB) environment. Today Info- Trans is a system that contains a database with all the information regarding the city's transport network. In May 2002 using the Geolog Road Base 2 (São Paulo City Road Base). All itineraries in effect at SPTrans were registered (geo-referenced), and this base has been incorporated into Info-Trans. In 2003 it was also carried out, as (Figure 2) a field survey of all points and shelters in the city of São Paulo and registered in the system.

Eduardo Facchini and Eduardo Mario Dias The Importance Of Development of Control Processes and Methods for Urban Bus Services
ADCAIJ: Advances in Distributed Computing and Artificial Intelligence Journal Regular Issue, Vol. 8 N. 3 (2019), 51-65 elSSN: 2255-2863 - http://adcaij.usal.es Ediciones Universidad de Salamanca - CC BY NC DC 


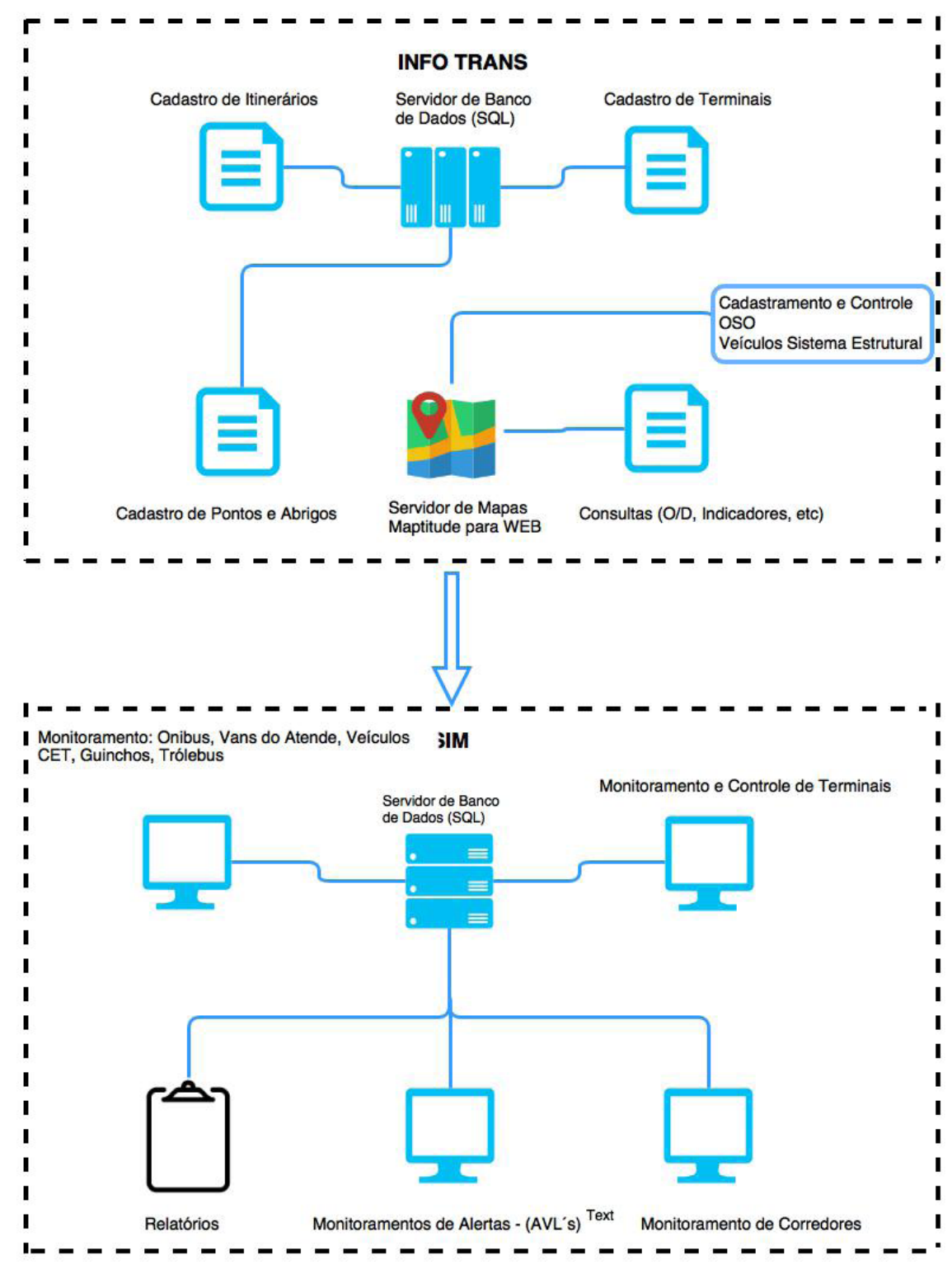

Figure 2: Schematic drawing of SPTrans Systems architecture.

\section{Source: May 2009 SPTrans Management and Revenue Board Report}

In November 2013, when a thematic chamber was created by the SPTrans Planning Board to study a solution to these problems, it was decided to conduct a pilot project to test new conceptual bases for the production of this service, as it showed how inefficient it was said to be with poor results and without proper strategy and operational tactics.

On this occasion, when researching the origin of the problem, it was verified the need to change some processes and operating routines and the new concept of Controlled Operation emerged.

The Controlled Operation places the operators as suppliers of fleet and human resources (crew on board) for the operation, and the Government, as the service manager, SPTrans, commands the Operational Control

Eduardo Facchini and Eduardo Mario Dias The Importance Of Development of Control Processes and Methods for Urban Bus Services
ADCAIJ: Advances in Distributed Computing and Artificial Intelligence Journal Regular Issue, Vol. 8 N. 3 (2019), 51-65 eISSN: 2255-2863 - http://adcaij.usal.es Ediciones Universidad de Salamanca - CC BY NC DC 
Center - CCO, the stage of operations, commanding the exit and the march of the vehicles. It also has support from the Traffic Engineering Company (CET) for the control of roadbed eventualities.

At the departure terminals, a vehicle inspection is carried out minutes before the vehicle is called an Operational Vehicle Inspection (IVO). The manager maintains a support team to check the basic conditions for the activity, such as lighting in case of night operation, the operation of the AVL - Automatic Vehicle Location data panel, among other items, and whether the driver and collector are registered and have undergone training. The cleanliness of the vehicle is also verified in this inspection.

A new strategy has also been put in place and deserves to be observed, with the creation of a new element in order to solve the problem of possible vehicle delays at planned exits. The Operational Reserve, a vehicle provided by the operators that remains available at the terminal, with crew prepared to assume in case of any eventuality with the normal line vehicle attending the command of the Operational Control Center - CCO of the manager (SPTrans).

At the same time, it was concluded that maximum use should be made of existing technology to improve the entire data flow and control parameters of the system. It should be remembered that until then, by the end of 2012, almost all technology involved in the system was used solely for the purpose of revenue control, and monitoring by SPTrans of some critical points. And also that the system was almost entirely in the hands of the operators and on them depended on the political will to exercise the intrinsic mechanisms of this technology to control the service offered, which was not for obvious reasons.

For the pilot project it was also determined that the experiment should be carried out at dawn, not only because it represents a new service offered to the population, recognizing that there was a latent demand in the city. In addition, also because it is the busiest time on the road, and it could be performed all necessary tests without the inconvenience of traffic.

It was also defined as a premise, follow best practices (Best practices. - Procedures standard for a particular type of business, process or business) of management in order to remedy the irregularities that scenario, following predefined rules for the taking decision The whole process was also defined and described in procedural manuals to ensure that each subsystem worked to support the decision maker.

Still on the historical evolution of the operation of public transport on tires in the city of São Paulo, from 2005 SPTrans began to monitor the operation of the public transport system on tires with the use of embedded equipment such as AVL - Automatic Vehicle Location. The equipment is mainly intended to inform the geographic position of the vehicle to the system manager and operator, using the GPS - Global Positioning System and GPRS - General Packet Radio Services, which has the function of sending the data collected by the $A V L$ equipment to the Data Center. from the public manager.

So we could say that theoretically, in order to start a test at that time, despite the past abandonment of these technologies, the tools available for controlling the São Paulo public transit system could have some accuracy with respect to fleet location. in operation.

We could also rely on other embedded equipment: such as a microphone, speaker and a data terminal that transmits information to the operations center and the driver of the vehicle as shown in Figure- 1 within sight and motor accessibility. The operation of the system still has the INFOTRANS system and can rely on the SIM - Integrated Monitoring System, which is shown in diagram in Figure-2, which provides the systematized information to the operators and the operations center.

It was observed during the dawn network pilot project that the staff involved in the operation had some bias towards the SIM system which led to several tests with the system and surprising discoveries about it. For example, the obvious as the recognition that the system was focused on monitoring and therefore did not fit the same control functions, function requested by the team. It turned out, therefore, that the operation's staff expected impossible things.

Another finding was that the failures found were communication, as the system uses GPS embedded in vehicles that works with a local cell phone chip that sometimes finds shadow zones making it impossible for satellite recognition. In addition to the total lack of maintenance made by operators in the $A V L$.

For a better understanding of the objective of the pilot project, a functional analysis of the proposed one follows, Figure - 3, where we show that the operation begins with the presentation of the vehicles by the companies and cooperatives with crew, in the determined terminals, where they undergo an inspection by the

Eduardo Facchini and Eduardo Mario Dias The Importance Of Development of Control Processes and Methods for Urban Bus Services
ADCAIJ: Advances in Distributed Computing and Artificial Intelligence Journal Regular Issue, Vol. 8 N. 3 (2019), 51-65 elSSN: 2255-2863 - http://adcaij.usal.es Ediciones Universidad de Salamanca - CC BY NC DC 
system manager or agents designated by it. They then go into operation when applicable as the work order also stipulated by SPTrans and return in natural sequence.

\section{OPERADORES: EMPRESAS E COPERATIVAS}

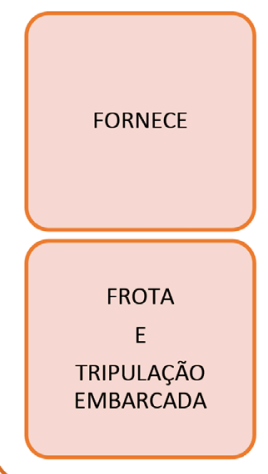

\section{GESTOR: SPTRANS}

INFRAESTRUTURA

DE TERMINAIS E

$\mathrm{CCO}$

EQUIPES DE CONTROLE

\section{USUÁRIO: PASSAGEIRO}

AFERE O SERVIÇO

Figure 3: Context Model Decomposition (We observed that in the context model decomposition presented, we did not identify the events that occur in the external environment, which provoke system response, nor did we present the details of its data flow s. simply illustrates the process flow and the spatial delimitation of the control object): System Interacting Elements - Action Flow - Primary Information Flow - Limits Set.

\section{Source: Author}

The fundamental innovations of the Controlled Operation include the control fully in the hands of the public manager and a crewed vehicle parked at the terminal, called Operational Reserve, awaiting eventualities and the order of the manager to supply in case of delay the vehicle in turn, although it can be used. at the discretion of the manager to cover other eventualities such as breakdown or non-presentation of vehicle in a timely manner by the operator.

\section{Complaints And The User's View - Justification}

The user's view should always be taken into consideration when it comes to services, especially public, because he carries the knowledge we do not have, his vision is that of everyday life. It gets where we can't get it, knows what happens, because it's present when we're not there and it's the first one to face the problem when it comes along, so we should by no means ignore the wisdom of the user. Therefore, from the report of the SPTrans Operating Board of June 2013, we have extracted some clarifications that will serve as the basis for the justification of the Controlled Operation pilot project, in which 12 lines were put into pilot operation, 3 of which are Structural and 09 are local. Table 1 of this report shows the typology of complaints collected in the customer service, made through line 156 of the City Hall. By checking the classification of complaints, we can have a slight indication of the flaws presented in the system.

Eduardo Facchini and Eduardo Mario Dias The Importance Of Development of Control Processes and Methods for Urban Bus Services
ADCAIJ: Advances in Distributed Computing and Artificial Intelligence Journal Regular Issue, Vol. 8 N. 3 (2019), 51-65 eISSN: 2255-2863 - http://adcaij.usal.es Ediciones Universidad de Salamanca - CC BY NC DC 
Quadro 1: Reclamações por tipo

\begin{tabular}{|c|c|c|c|}
\hline \multicolumn{2}{|r|}{ TIPO DE RECLAM AÇÃO } & \multirow{2}{*}{\begin{tabular}{|c|} 
QTDE. \\
2244 \\
\end{tabular}} & \multirow{2}{*}{$\begin{array}{c}\% \\
36,67 \% \\
\end{array}$} \\
\hline $1^{\circ}$ & Motorista não atender embarque / desembarque & & \\
\hline $2^{\circ}$ & Conduzir o veículo com direção perigosa & 1115 & $18,22 \%$ \\
\hline $3^{\circ}$ & Conduta Inadequada do operador & 1011 & $16,52 \%$ \\
\hline $4^{\circ}$ & Tratar usuário / público com falta urbanidade/des trato & 368 & $6,01 \%$ \\
\hline $5^{\circ}$ & Motorista não aguardar embarque/des embarque & 306 & $5,00 \%$ \\
\hline $6^{\circ}$ & Interromper / atras ar propositalmente a viagem & 197 & $3,22 \%$ \\
\hline $7^{\circ}$ & Motorista alterando Itinerário previs to & 145 & $2,37 \%$ \\
\hline $8^{\circ}$ & Tratar o idoso com falta de urbanidade / Des trato & 126 & $2,06 \%$ \\
\hline $9^{\circ}$ & Cobrador reter a tarifa em prov eito próprio & 91 & $1,49 \%$ \\
\hline $10^{\circ}$ & Agressão física / Ameaça & 65 & $1,06 \%$ \\
\hline $11^{\circ}$ & Embarcar / des embarcar afas tado do meio fio & 54 & $0,88 \%$ \\
\hline $12^{\circ}$ & Trafegar pela segunda faixa de rolamento & 51 & $0,83 \%$ \\
\hline $13^{\circ}$ & Deixar de cobrar tarifa / Gratuidade injus tificada & 48 & $0,78 \%$ \\
\hline $14^{\circ}$ & Operador fumando dentro do veiculo & 36 & $0,59 \%$ \\
\hline $15^{\circ}$ & A pres entar sinais de embriaguez em serviço & 33 & $0,54 \%$ \\
\hline $16^{\circ}$ & Motorista convers ar ao volante & 32 & $0,52 \%$ \\
\hline $17^{\circ}$ & Pass ageiro es pecial impedido de embarcar & 30 & $0,49 \%$ \\
\hline $18^{\circ}$ & Alteração ponto inicial/final s em autorização da SPTrans & 25 & $0,41 \%$ \\
\hline $19^{\circ}$ & Problemas com troco & 23 & $0,38 \%$ \\
\hline $20^{\circ}$ & Luzes do letreiro apagadas em horário noturno & 19 & $0,31 \%$ \\
\hline $21^{\circ}$ & Praticar atos que atentem a moral e bons costumes & 18 & $0,29 \%$ \\
\hline $22^{\circ}$ & Recus a em prestar informação / informação errada & 17 & $0,28 \%$ \\
\hline $23^{\circ}$ & Permitir atuação de vendedores ambulantes & 17 & $0,28 \%$ \\
\hline $24^{\circ}$ & Conduta de motoris ta do Serviço ATENDE & 11 & $0,18 \%$ \\
\hline $25^{\circ}$ & Trafegar com as portas abertas & 9 & $0,15 \%$ \\
\hline $26^{\circ}$ & Letreiro em desacordo/placas incorretas/aus entes & 9 & $0,15 \%$ \\
\hline $27^{\circ}$ & Estacionado ponto inicial / final com portas fechadas & 6 & $0,10 \%$ \\
\hline $28^{\circ}$ & Não portar identificação / má apres entação pessoal & 6 & $0,10 \%$ \\
\hline $29^{\circ}$ & Ameaça com arma & 5 & $0,08 \%$ \\
\hline $30^{\circ}$ & Utilização irregular de Bilhete Único & 3 & $0,05 \%$ \\
\hline \multicolumn{2}{|r|}{ TOTAL } & 6120 & $100 \%$ \\
\hline $1^{\circ}$ & Intervalo excessivo da linha & 4098 & $80,96 \%$ \\
\hline $2^{\circ}$ & Descumprir ou não realizar partidas programadas & 779 & $15,39 \%$ \\
\hline $3^{\circ}$ & Veículo com superlotação & 137 & $2,71 \%$ \\
\hline $4^{\circ}$ & Demora na partida do coletivo & 34 & $0,67 \%$ \\
\hline $5^{\circ}$ & Não cumprir partida programada veículos adaptados & 10 & $0,20 \%$ \\
\hline $6^{\circ}$ & Não cumprimento de horário Serviço ATENDE & 4 & $0,08 \%$ \\
\hline \multicolumn{2}{|r|}{ TOTAL } & 5062 & $100 \%$ \\
\hline $1^{\circ}$ & Mau estado de cons ervação do veículo em geral & 97 & $36,47 \%$ \\
\hline $2^{\circ}$ & Problemas mecânicos & 86 & $32,33 \%$ \\
\hline $3^{\circ}$ & Falta de limpeza interna / externa dos veículos & 57 & $21,43 \%$ \\
\hline $4^{\circ}$ & Problemas no sis tema de iluminação interna do veiculo & 9 & $3,38 \%$ \\
\hline $5^{\circ}$ & Catraca Eletrônica / Validador não funciona & 9 & $3,38 \%$ \\
\hline $6^{\circ}$ & Veículo com emissão de fumaça preta & 3 & $1,13 \%$ \\
\hline $7^{\circ}$ & Falta de bancos reservados à passageiros especiais & 3 & $1,13 \%$ \\
\hline $8^{\circ}$ & Veículo com vazamento de óleo & 2 & $0,75 \%$ \\
\hline \multicolumn{2}{|r|}{ TOTAL DE RECLAMAÇÕES FEITAS SOBRE A FROTA } & 266 & \multirow[b]{2}{*}{$100 \%$} \\
\hline & TOTAL GERAL & 11.448 & \\
\hline
\end{tabular}

Fonte: Relatório Diretoria de Operações da SPTrans - junho de 2013.

Eduardo Facchini and Eduardo Mario Dias The Importance Of Development of Control Processes and Methods for Urban Bus Services
ADCAIJ: Advances in Distributed Computing and Artificial Intelligence Journal Regular Issue, Vol. 8 N. 3 (2019), 51-65 eISSN: 2255-2863 - http://adcaij.usal.es Ediciones Universidad de Salamanca - CC BY NC DC 
In analyzing user complaints, we note that many of them could be mitigated through the operating strategies provided for in the Controlled Operation:

Regularity issues: excessive range $(4,098)$; non-compliance with scheduled departures (779), deliberate interruption or delay of travel (197), overcrowding (137); delay in the departure of the collective (34). These complaints total 5,245 complaints, which corresponds to $45.81 \%$ of the total of the month analyzed;

- Itinerary issues: driver changing planned route (145); change of the starting and / or ending point without SPTrans authorization (25). These complaints total 170 complaints, representing $1.48 \%$ of the total of the month analyzed;

- And issues related to fleet condition: poor vehicle condition (97), mechanical problems (86) and poor vehicle cleanliness (57). These complaints total 240 complaints, representing $2.09 \%$ of the total of the period analyzed.

From the data analyzed, we can conclude that the Controlled Operation could reduce, when deployed in the system as a whole, at least $49.38 \%$ user complaints, representing a significant improvement in the quality of bus services in the city of São Paulo.

In Table-2 we present the structure used for the formation of the pilot project, the relationship of the structural lines and locations used and the operators that attended during the project period

\section{Pilot Project}

Table 02: List of Structural Lines and Locations of the Controlled Operation Pilot Project

\begin{tabular}{|c|c|c|c|}
\hline \multicolumn{2}{|c|}{ ESTRUTURAIS } & FROTA & OPERADORA \\
\hline 1 & TERM JD ÂNGELA - TERM S. AMARO (PASSAGEM T. GUARAPIRANGA) & 8 & CAMPO BELO \\
\hline 2 & TERMINAL PIRITUBA - TERMINAL LAPA & 3 & STA BRIGIDA \\
\hline 3 & TERM. A. E. CARVALHO - TERM. PQ. D. PEDRO II & 2 & VIP - 3 \\
\hline \multicolumn{2}{|c|}{ SUBTOTAL } & 13 & \\
\hline \multicolumn{2}{|c|}{ LOCAIS } & FROTA & OPERADORA \\
\hline 1 & TERM. JD. ÂNGELA - PARQUE DO LAGO & 2 & COOPER PAM - 7 \\
\hline 2 & TERM. JD. ÂNGELA - JD. HORIZONTE AZUL & 2 & COOPER PAM - 7 \\
\hline 3 & TERM. JD. ÂNGELA - JD. RIVIERA & 2 & COOPER PAM - 7 \\
\hline 4 & TERM. PIRITUBA - CIDADE D'ABRIL 3ª GLEBA & 2 & STA BRIGIDA \\
\hline 5 & TERM. PIRITUBA - JD. DONARIA & 2 & STA BRIGIDA \\
\hline 6 & TERM. PIRITUBA - VILA MIRANTE & 1 & TRANSCOOPER \\
\hline 7 & TERM. A. E. CARVALHO - JD. ROBRU & 2 & VIP - 3 \\
\hline 8 & TERM. A. E. CARVALHO - OLIVEIRINHA & 3 & VIP - 3 \\
\hline 9 & TERM. A E CARVALHO - VILA CISPER (CPTM USP) & 2 & TRANSCOOPER \\
\hline \multicolumn{2}{|c|}{ SUBTOTAL } & 18 & \\
\hline \multicolumn{2}{|r|}{ TOTAL DE FROTA NA ETAPA 1} & 31 & \\
\hline
\end{tabular}

Fonte: Apresentação Diretoria de Planejamento de Transportes da SPTrans- março 2015.

The pilot project was successful about the new conceptual bases for the production of the service, the SPTrans team and the operators proved to be intertwined and the processes efficient and effective.

The Government took control of the operation and showed a good performance when in the action of clearance of the road used by buses, companies and cooperatives provided the fleet and teams with trained staff and

Eduardo Facchini and Eduardo Mario Dias The Importance Of Development of Control Processes and Methods for Urban Bus Services
ADCAIJ: Advances in Distributed Computing and Artificial Intelligence Journal Regular Issue, Vol. 8 N. 3 (2019), 51-65 eISSN: 2255-2863 - http://adcaij.usal.es Ediciones Universidad de Salamanca - CC BY NC DC 
vehicles relatively under the required conditions. Experience has shown a high result in the number of departures without delay and a high degree of regularity in the operation, as shown in Graphs 1 and 2.

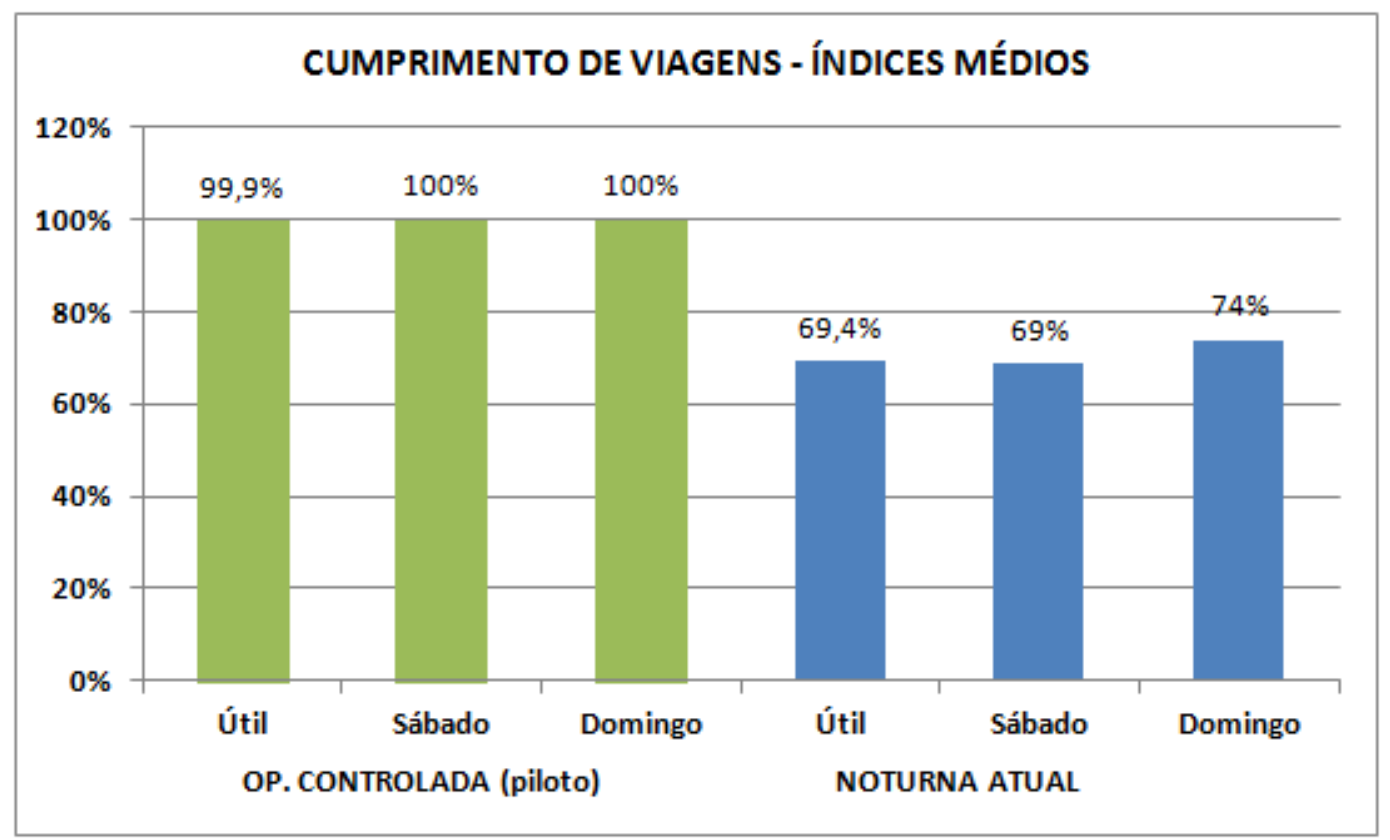

Graph 1: Survey conducted from 04 to 10/08/2015 in the hours of 00h00 to 04h00.

Source: Presentation Transportation Planning Board of SPTrans- March 2015.

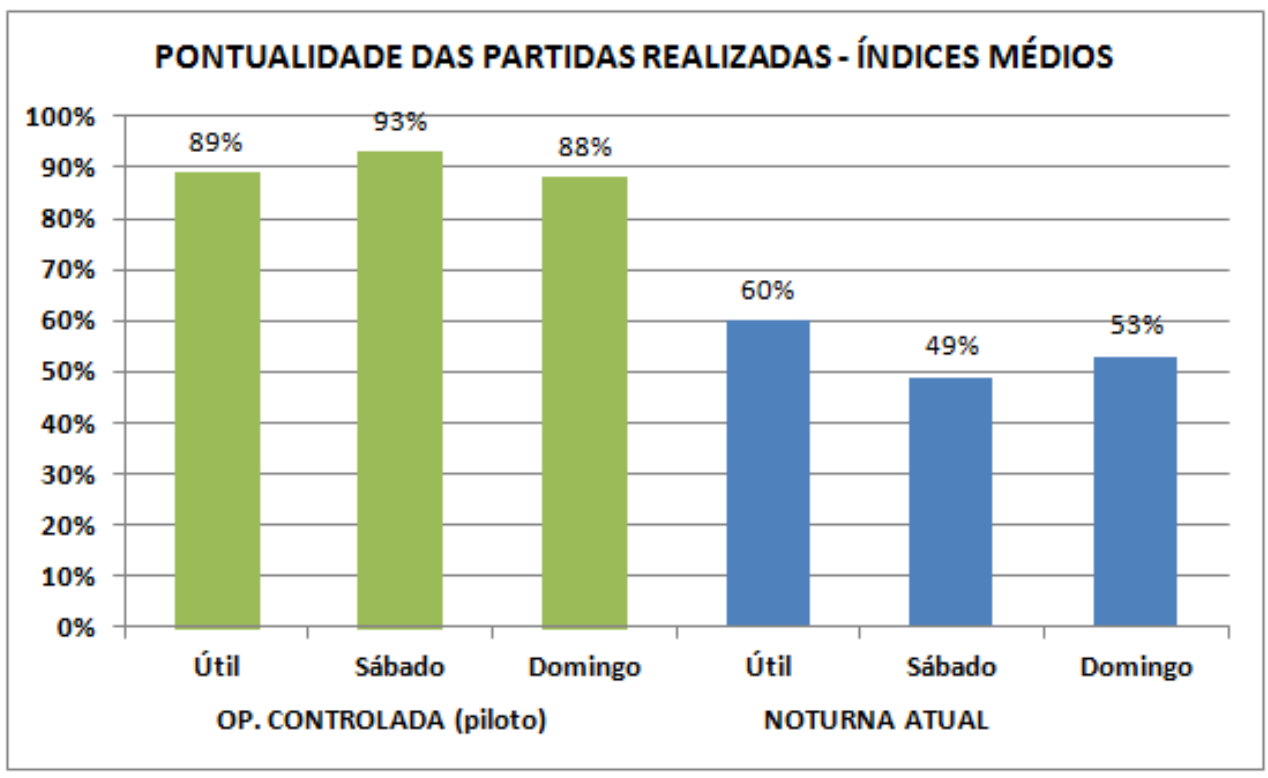

Grafico 02: Levantamento realizado pelo SIM entre 04 a 10/08/2015 no horário das $00 h 00$ às $04 h 00$.

Fonte: Apresentação Diretoria de Planejamento de Transportes da SPTrans- março 2015.

Eduardo Facchini and Eduardo Mario Dias

The Importance Of Development of Control Processes and

Methods for Urban Bus Services
ADCAIJ: Advances in Distributed Computing and Artificial Intelligence Journal Regular Issue, Vol. 8 N. 3 (2019), 51-65 elSSN: 2255-2863 - http://adcaij.usal.es Ediciones Universidad de Salamanca - CC BY NC DC 
It is important to remember that Controlled Operation should achieve a better level of performance when the new network is fully deployed with the new itineraries avoiding line overlaps and allowing greater coverage in the city's geography. Their connection points should also be considered, offering new possibilities of displacement to the system user population, all through the benefits of the intensive use of the Single Ticket.

\section{Results, Considerations And Contributions}

In this case study we present aspects related to the control of the bus operation in the city of São Paulo and its importance, besides showing a brief history of how the current stage of the bus system control in the city was reached and a brief idea of the proposal. which has been the subject of studies to achieve better results in this service, the Controlled Operation. That will surely deserve an in-depth study of its methodology and implementation process in the future if all goes as planned.

We can also verify from the problems presented and from the results of SPTrans research, (Table 1), exposed here, that the operation of bus transportation services in the city has neither presented nor had adequate results and still does not attend the population. satisfactorily.

From the exploratory analysis of the literature we saw that there are different types and various forms of control objects and in this case, we cannot give up any of them. The lack of a more effective and efficient model has led the city's bus system to standards considered to be very weak in all aspects presented here.

According to Cunningham (1992), there are two categories of management control. One concerns the controls results or products, including covering the monitoring functions of administrative controls, operating controls and INDICATORS s quality, break per kilometer or Mean Kilometer Between Failure (MKBF), starting compliance and others.

The other involves people controls, by training human resources, managers and operators, which may be related to rules, procedures, selection criteria for hiring personnel, design and placement of jobs and qualitative survey of resources. In an organization similar to the operation of the urban bus service, we have several elements to control, with responsibilities that can be established in a number of ways.

The truth is that unfortunately we cannot let machines and equipment take over the control as we saw in an open system. Unlike the famous phrase attributed to Warren Bennis $\mathrm{PhD}$, founder and president of the USC's Leadership Institute: "That the factory of the future will have only two employees, one man and one dog. The man will be there to feed the dog. The dog will be there to prevent the man from touching the equipment ". (OLIVEIRA, 2015, p.1)

In the case of São Paulo, this high level of automation does not exist yet. We will only find some process automation in some subsystems of the Transport Service Operation Management cycle, such as system monitoring with the SIM - Integrated Monitoring System.

It is also worth remembering that in the current system the responsibility for control is still shared, and for the managing body control is exercised by fines and coercive methods leaving it to the operators to comply with service orders, which sometimes, due to cost, operator benefit and interest are not met. An important aspect for the efficiency of the control system, recalled by Lunkes (2010), is that the control is not done by a manager appointed or appointed by the controlled and cites as an example of this improper procedure the occasional practice in public administration.

We know that the search for effective and efficient control does not end here in the case of public management of this type of service, but the issue of controlling what we pay with public money must and must be taken seriously, and it is also important. consider the cost for this control.

The experience of SPTrans dawn lines, using the Controlled Operation methodology, has been shown to be viable by the results obtained by the pilot project, regarding their efficiency and effectiveness in controlling the urban bus transport service in the city of São Paulo, which is why the current management of SPTrans will implement a complete system foreseeing a network of night lines operated with this model. (FREDERICO; PEREIRA, 2015).

The Controlled Operation will play a key role in the Operational Management of São Paulo's transport, not only in Rede da Madrugada, but also in the entire new restructuring of the city's transport network, which is expected to take place gradually until mid-2016. Weekend Network, Between Peak and Peak, will also be based on Controlled Operation, as a control methodology and as a new operation system. The positive experience

Eduardo Facchini and Eduardo Mario Dias The Importance Of Development of Control Processes and Methods for Urban Bus Services
ADCAIJ: Advances in Distributed Computing and Artificial Intelligence Journal Regular Issue, Vol. 8 N. 3 (2019), 51-65 eISSN: 2255-2863 - http://adcaij.usal.es Ediciones Universidad de Salamanca - CC BY NC DC 
gained at the Dawn Network or as the name given by the Night Network administration, however, in our view will only be repeated if the established procedures and rules are followed.

For this reason, we consider the control by the public power of this service of crucial importance for the bus transportation service, not only for the essential deference of the control of the public expenses, but for the primordial character of offering the city the condition of quality displacement by the city where you live.

\section{Bibliographic References}

Aguero, R.a. The construction of discourse on child labor: media, images and power. 2015. Dissertation (Master) - Graduate Program in Letters, Concentration Area Linguistic Studies, Federal University of Mato Grosso do Sul, 2008. Available at: http://www.ibamendes.com/2011/02/foucault -and-his-to-discipline-power. html Accessed: 10/14/2015

Armstrong-Wright, A. Urban Transit Systems: guidelines for examining options. WBTP no. 52. Washington DC: The Word Bank, 1986

Brazilian, A. et al. Road unlimited. Sao Paulo: Culture, 1999.

Chiavenato, I. Introduction to the general theory of administration. 6. ed. Rio de Janeiro: Campus, 2000.

Cruz, MVG Production of the urban public bus service: aspects of work organization. Journal of Contemporary Management, v. 2, no. 3, pp. 45-65, 1998.

Oliveira Neto, F.M. Prioritization of public transport by bus traffic. [sl] 2004.

Cunningham, G.M. Management and accounting systems under competitive strategy. Accounting, Auditing \& Accountability Journal, v.5, n. 2, pp. 85-102, 1992.

Elaina, J. Henri Fayol - Father of Classical Administration Theory Available at: http://www.portal-gestao.com/ item/6886-henri-fayol-pai-da-theory cl\% C3\% \% C3\% A7\% C3\% A3o.html Accessed on: Dec. 2014.

Fayol, H. Industrial and General Administration. Sao Paulo: Atlas, 1981.

Foucault, M. Watch and punish birth of prison. Petrópolis: Voices, 2014.

Frederico, C.s.; Pereira, A.l.s. Controlled Operation of Night Lines: Case Study at SPTRANS. Work completion course PTR5917. its - Intelligent Transport Systems - (preliminary version of article to be presented). Polytechnic School of the University of São Paulo - USP - São Paulo - 2015.

Gualazzi, E.1.b. Legal regime of the Court of Auditors. São Paulo: Review of the Courts, 1992.

IBGE, available at http://www.ibge.gov.br/home/estatistica/populacao/estimativa2014/estimativa_dou.shtm accessed December 2014.

Jannuzzi, P. et al., Structuring of monitoring systems and specification of evaluation research, the problems of public programs in Brazil. In: ENAP. Social Program Evaluation. Brasília, Enap - EIAPP, 2009 p. 124.

Lunkes, R.J. Management Control - strategic, tactical, operational, internal and risky. Sao Paulo: Atlas, 2010.

Moraes, A.C.; Facchini, E.; Bovo, C.R.M. Planning and transport urban mobility at the crossroads: urgent debate, urgent solutions. Public Transport Magazine - ANTP, v. $3^{\text {the }}$ quadrim, p. 8, 2014.

Mosimann, C.P.; Fisch, S. Controllership. 2. ed. Sao Paulo: Atlas, 1999.

Oliveira, R.A. The line of tomorrow. Available at http://www.softword.com/gestao_1.htm - accessed March 2015.

SPTRANS. REPORT OF THE MANAGEMENT BOARD. SPTrans - computerized systems for the management of public transportation in the city of. - MAY / 2009.

SPTRANS. REPORT OF COMPLAINTS. SPTrans Operations Directorship, 2014.

SPTRANS. São Paulo Transporte SA Available at: http://www.sptrans.com.br/a_sptrans/Accessed: 08/10/2015.

Eduardo Facchini and Eduardo Mario Dias

The Importance Of Development of Control Processes and

Methods for Urban Bus Services
ADCAIJ: Advances in Distributed Computing and Artificial Intelligence Journal Regular Issue, Vol. 8 N. 3 (2019), 51-65 eISSN: 2255-2863 - http://adcaij.usal.es Ediciones Universidad de Salamanca - CC BY NC DC 
